J. Clin. Chem. Clin. Biochem.

Vol. 18, 1980, pp. 545-549

\title{
Thromboplastic Activity of Human Arterial Walls and its Interaction with the Plasmatic Coagulation System
}

By H. Zaugg

\section{F. Hoffmann-La Roche \& Co. Ltd., Diagnostic Research Department, Basel}

(Received November 6, 1979/April 1, 1980)

Summary: Intact arterial vessel wall is not thrombogenic. Disorders of the endothelium in connection with pathological conditions such as atherosclerosis, hyperlipidaemia, hypertension and hyperuricemia induce interaction of surfaces of high thromboplastic activity with the blood stream. In such situations local formation of thrombin will take place immediately. Evidence is presented for the essential and unique activation of the extrinsic pathway of the plasmatic coagulation system. The local formation of thrombin at pathologically altered arterial wall seems to be an important trigger for arterial thrombosis and haemostasis. It could be that in vivo the initial step of thrombogenesis depends upon the formation of the activator complex between tissue-thromboplastin and factor VII.

\section{Thromboplastin-Aktivität in humanen arteriellen Gefäßwänden und ihre Wirkung auf das plasmatische Gerinnungs- system}

Zusammenfassung: Die intakte arterielle Gefäßwand ist nicht thrombogen. Bei Endothel-Schädigungen, ausgelöst durch pathologische Bedingungen wie Atherosklerose, Hyperlipidämie, Hypertonie und Hyperurikämie, erscheint Thromboplastin-Aktivität an der Oberfläche und reagiert mit dem Blutstrom. Unter solchen Umständen tritt dort sofort lokaliṣierte Thrombinbildung ein. Resultate der eigenen experimentellen Untersuchungen bestätigen die Aktivierung des plasmatischen Gerinnungssystems über den extrinsischen Reaktionsablauf. Dabei kommt der lokalisierten Thrombinbildung an pathologisch veränderten Gefäßen eine Bedeutung in der arteriellen Thrombose- und Hämostase-Auslösung zu. Für die Thrombogenese muß die Bildung des Aktivator-Komplexes zwischen Thromboplastin und Faktor VII als Initial-Reaktion angesehen werden.

\section{Introduction}

The subendothelial tissue and the endothelial cells themselves contain high thromboplastic activity (1). Tissue-thromboplastin fixed in the microsomal biomembrane is the specific physiological activator of the extrinsic blood clotting pathway. Under pathological conditions the thromboplastic activity comes into contact with the blood. A highly specific and rapid activation of factor VII followed by thrombin formation at the disordered vessel wall position can be assumed. The high affinity of thrombin to thrombocytes and fibrinogen under physiological conditions may initiate systemic thrombin formation with eventual consequences such as myocardial infarction, cerebral stroke, pulmonary embolism (2).

Our studies are designed to elucidate the initial reaction, i.e. formation of a complex between wall-localized throm- boplastin and factor VII. It is likely that this step is at the very beginning of early events in arterial thrombogenesis.

\section{Material and Methods}

\section{Human arterial vessels}

Aortic material (aorta abdominalis) was kindly supplied by Prof. L. Bianchi, Pathological Institute of the University of Basel. Surgical specimens of arterial vessel segments were kindly provided by Dr. B. Nachbur, Surgical Department, Inselspital Bern. Vessel segments were kept in Tris-buffered saline $\mathrm{pH} 7.4$ at $4{ }^{\circ} \mathrm{C}$. The connective tissue at the outside was carefully removed and the buffer-solution changed several times to remove most of blood contaminants.

For the experiments the vessels were cut off alongside and divided in square parts of $1 \mathrm{~cm}^{2}$. With respect to the degree of alteration of the arterial wall, the segments were tentatively classified into those with atherosclerotic plaques, 
severe atherosclerotic ulceration, wall thickening with entrapped hydroxyapatite and/or cholesterol parts.

Near normal arterial wall specimens were also obtained for our investigations from patients undergoing surgery.

\section{Plasma}

Normal human citrated plasma was prepared from blood collected at the Swiss Red Cross Blood Bank, Kantonsspital Basel, 9 vol. to 1 vol. of $0.1 \mathrm{~mol} / 1$ sodium citrate solution. The blood samples were centrifuged immediately at $1500 \mathrm{~g}$ for 20 minutes. Plasma specimens from 20 donors were pooled and shock-frozen in aliquots of $2.0 \mathrm{ml}$.

Factor VII-deficient plasma was obtained from GEORGE KING Bio-Medical Corp., USA. The frozen plasma represented a congenital, factor VII-deficient human plasma from a single donor with a factor VII activity $\leqslant 1 \%$ of normal according to the declaration.

Diagnostic reagents like $\mathrm{Ca}$ thromboplastin and partial thromboplastin time reagent were manufactured by Diagnostica ROCHE, Basel. Solutions of $0.025 \mathrm{~mol} / \mathrm{l}$ calcium chloride, $0.2 \mathrm{~mol} / 1$ trisodium citrate and saline were prepared with commercial substances of p.a. grade.

\section{Clotting time measurement}

All clotting time measurements except recalcification time, were determined by use of the BBL-Fibrometer.

Recalcification time was determined as follows: $1.0 \mathrm{ml}$ of plasma without or with added vessel segment was incubated for 3 minutes at $37^{\circ} \mathrm{C}$. Then $1.0 \mathrm{ml}$ of $0.025 \mathrm{~mol} / \mathrm{l}$ calcium chloride solution prewarmed to $37^{\circ} \mathrm{C}$ was added at once and coagulation time measured by the manual tilt-tube technique in a $37^{\circ} \mathrm{C}$ water bath.

For prothrombin time determination $0.2 \mathrm{ml}$ prewarmed $\left(37^{\circ} \mathrm{C}\right)$ Ca thromboplastin ROCHE solution was added to $0.1 \mathrm{ml}$ plasma, preincubated or not with a vessel-segment. The clotting time was measured with the BBL-Fibrometer.

For partial thromboplastin time estimation, $0.1 \mathrm{ml}$ plasma (as used for prothrombin time determination) and $0.1 \mathrm{ml}$ partial thromboplastin time reagent ROCHE were mixed and preincubated at $37^{\circ} \mathrm{C}$ for 3 minutes. Then $0.1 \mathrm{ml}$ prewarmed $\left(37^{\circ} \mathrm{C}\right) 0.025 \mathrm{~mol} / 1 \mathrm{calcium}$ chloride solution was added and the clotting time determined with the BBL-Fibrometer.

\section{Results}

Alterations of prothrombin time and partial thromboplastin time of normal and factor VII-deficient plasma, preincubated with vessel segment

Arterial wall segments (from aorta abdominalis) with a surface area of $1 \mathrm{~cm}^{2}$ were added to $2.0 \mathrm{ml}$ of normal citrated human plasma or to factor VII-deficient human plasma. After 15 minutes with occasional agitation at room temperature the plasmas were harvested with a pipette and tested immediately by prothrombin time and partial thromboplastin time measurements. Results are summarized in table 1.

Slight increases of prothrombin time from 14.5 to 15.7 seconds for normal plasma and from 22.3 to 23.4 seconds for factor VII-deficient plasma were observed. No difference was noticed between vessel material from dissection and from surgery. Preincubation of normal plasma with pathologically altered specimens of vessel-wall does not give effects detectable with prothrombin time. The prothrombin time values seem to be influenced by the action of citrate in human citrated plasma. Its strong calcium chelation effect inhibits the formation of the complex between factor VII and the thromboplastic activity localized on wall damage. To study this effect the plasma recalcification time was determined in the absence or presence of vessel segments. Results are given in the next experimental part. The increase of partial thromboplastin time in the measurement with factor VII-deficient plasma could be induced by adsorption of factor XII onto damaged vessel surface. No increase of partial thromboplastin time is detectable by incubation of plasma with normal non-disordered vessels, i.e. vessel from surgery patient (accident leg amputation).

\section{Influence of vessel segments added to plasma upon recalcification time}

Table 2 contains the values obtained with normal and factor VII-deficient plasma. As can be seen, recalcification time values were markedly decreased, especially in normal human plasma, whereas in factor VII-deficient plasma, recalcification time reduction was less pronounced. In these experiments, citrate action on $\mathrm{Ca}$ complexation was eliminated and the formation of an activator complex between thromboplastin and factor VII and other Ca-dependent reaction steps was not inhibited.

\section{Recalcification time values of fresh normal human citrated plasma incubated with the same vessel segment after several preincubations in normal plasma}

A denuded aorta segment (surface area $1 \mathrm{~cm}^{2}$ ) was placed into $1.0 \mathrm{ml}$ of normal human plasma and prewarmed for 2 minutes at $37^{\circ} \mathrm{C}$. Recalcification time was then estimated by adding $1.0 \mathrm{ml}$ solution of 0.025 $\mathrm{mol} / \mathrm{l} \mathrm{CaCl} 2$. At the end of clotting the segment was removed, freed from any adhering fibrin clot, washed with saline and recalcification time estimations repeated with this segment and fresh plasma. After this second determination, the procedure of fibrin elimination was repeated. The segment was either washed with saline or with a solution of $0.2 \mathrm{~mol} / 1$ sodium citrate. Before. adding the segments to fresh plasma, normal and factor VII-deficient, contaminating solution was removed with filter paper.

Figure 1 summarizes the results of these experiments. After the first recalcification time estimation in the presence of the vessel segment, the values decreased; the second preincubation was followed by a further 
Tab. 1. Alterations of prothrombin time and partial thromboplastin time values of normal and factor VII-deficient plasma after preincubation with "normal" and disordered vessel (aorta abdominalis) segments.

a) Vessel segments from obduction (aorta abdominalis).

\begin{tabular}{|c|c|c|c|c|c|c|}
\hline \multirow{2}{*}{$\begin{array}{l}\text { Patient } \\
\text { Code }\end{array}$} & \multirow{2}{*}{$\begin{array}{l}\text { Age } \\
\text { (a) }\end{array}$} & \multirow[t]{2}{*}{ Diagnosis } & \multicolumn{2}{|c|}{ Prothrombin time (s) } & \multicolumn{2}{|c|}{ Partial thromboplastin time (s) } \\
\hline & & & Normal plasma & $\begin{array}{l}\text { Factor VII- } \\
\text { deficient } \\
\text { plasma }\end{array}$ & Normal plasma & $\begin{array}{l}\text { Factor VII- } \\
\text { deficient } \\
\text { plasma }\end{array}$ \\
\hline $\begin{array}{l}81^{\prime} 878 \\
83^{\prime} 478 \\
83^{\prime} 778 \\
85^{\prime} 378 \\
87^{\prime}(778 \\
87^{\prime} 278 \\
87^{\prime} 378 \\
88^{\prime} 378 \\
88^{\prime} 478\end{array}$ & $\begin{array}{l}76 \\
90 \\
80 \\
86 \\
75 \\
66 \\
71 \\
81 \\
71\end{array}$ & $\begin{array}{l}\text { Bronchial carcinoma } \\
\text { Myocardial infarct (death) } \\
\text { Pneumonia } \\
\text { Pneumonia } \\
\text { lleus/Pneumonia } \\
\text { Urinary bladder carcinoma } \\
\text { Pneumonia } \\
\text { Myocardial infarct (death) } \\
\text { Myocardial infarct (death) }\end{array}$ & $\begin{array}{l}15.3 \\
15.5 \\
16.5 \\
15.3 \\
15.1 \\
16.3 \\
15.4 \\
16.0 \\
15.7\end{array}$ & $\begin{array}{l}20.3 \\
24.8 \\
26.1 \\
21.3 \\
22.2 \\
25.3 \\
23.8 \\
24.8 \\
22.3\end{array}$ & $\begin{array}{l}29.1 \\
28.5 \\
28.6 \\
31.0 \\
31.3 \\
29.1 \\
31.6 \\
28.5 \\
28.1\end{array}$ & $\begin{array}{l}61.5 \\
64.8 \\
68.8 \\
64.1 \\
63.3 \\
61.5 \\
70.4 \\
67.9 \\
61.9\end{array}$ \\
\hline \multicolumn{3}{|c|}{ Average from 9 samples } & 15.7 & 23.4 & 29.5 & 64.9 \\
\hline \multicolumn{3}{|c|}{ Standard deviation } & \pm 0.5 & \pm 2.0 & $\pm \overline{1.4}$ & $\pm \overline{3.4}$ \\
\hline \multirow{2}{*}{\multicolumn{3}{|c|}{ Values without wall contact }} & 14.5 & 22.3 & 29.8 & 33.2 \\
\hline & & & \pm 1.0 & \pm 2.0 & \pm 2.5 & \pm 5.0 \\
\hline
\end{tabular}

b) Vessel segments from surgery (arteries).

\begin{tabular}{|c|c|c|c|c|c|c|}
\hline \multirow{2}{*}{$\begin{array}{l}\text { Patient } \\
\text { Code }\end{array}$} & \multirow{2}{*}{$\begin{array}{l}\text { Age } \\
\text { (a) }\end{array}$} & \multirow[t]{2}{*}{ Diagnosis/Remarks } & \multicolumn{2}{|c|}{ Prothrombin time (s) } & \multicolumn{2}{|c|}{ Partial thromboplastin time (s) } \\
\hline & & & Normal plasma & $\begin{array}{l}\text { Factor VII- } \\
\text { deficient } \\
\text { plasma }\end{array}$ & Normal plasma & $\begin{array}{l}\text { Factor VII- } \\
\text { deficient } \\
\text { plasma }\end{array}$ \\
\hline $\begin{array}{l}\text { MN } \\
\text { PW } \\
\text { TS } \\
\text { B }\end{array}$ & $\begin{array}{l}46 \\
73 \\
53 \\
63\end{array}$ & $\begin{array}{l}\text { Accident leg amputation } \\
\text { Atherosclerotic plaques ulc. } \\
\text { Atherosclerotic plaques } \\
\text { Atherosclerosis }\end{array}$ & $\begin{array}{l}14.5 \\
15.1 \\
15.3 \\
15.1\end{array}$ & $\begin{array}{l}30.3 \\
30.7 \\
22.5 \\
19.8\end{array}$ & $\begin{array}{l}27.5 \\
28.6 \\
37.1 \\
30.8\end{array}$ & $\begin{array}{l}35.5 \\
32.6 \\
75.3 \\
66.1\end{array}$ \\
\hline \multicolumn{3}{|c|}{ Average from 4 samples } & 15.0 & 25.8 & $\underline{31.0}$ & $\underline{52.4}$ \\
\hline \multicolumn{3}{|c|}{ Standard deviation } & \pm 0.3 & \pm 5.5 & \pm 4.3 & \pm 21.5 \\
\hline \multirow{2}{*}{\multicolumn{3}{|c|}{ Values without wall contact }} & $\underline{14.5}$ & $\underline{22.3}$ & 29.8 & $\underline{33.2}$ \\
\hline & & & \pm 1.0 & \pm 2.0 & \pm 2.5 & \pm 5.0 \\
\hline
\end{tabular}

Tab. 2. Influence of normal and factor VII-deficient plasma on the recalcification time in the presence of altered vessel segments.

\begin{tabular}{|c|c|c|c|c|}
\hline \multirow{2}{*}{$\begin{array}{l}\text { Patient } \\
\text { Code }\end{array}$} & \multirow{2}{*}{$\begin{array}{l}\text { Age } \\
\text { (a) }\end{array}$} & \multirow[t]{2}{*}{ Diagnosis } & \multicolumn{2}{|c|}{ Realcification time (s) } \\
\hline & & & Normal plasma & $\begin{array}{l}\text { Factor VII- } \\
\text { deficient plasma }\end{array}$ \\
\hline $\begin{array}{l}81^{\prime} 878 \\
83^{\prime} 478 \\
83^{\prime} 778 \\
85^{\prime} 378 \\
87^{\prime} 078 \\
87^{\prime} 278 \\
87^{\prime} 378 \\
88^{\prime} 378 \\
88^{\prime} 478\end{array}$ & $\begin{array}{l}76 \\
90 \\
80 \\
86 \\
75 \\
66 \\
71 \\
81 \\
71\end{array}$ & $\begin{array}{l}\text { Bronchial carcinoma } \\
\text { Myocardial infarct (death) } \\
\text { Pneumonia } \\
\text { Pneumonia } \\
\text { Ileus/Pneumonia } \\
\text { Urinary bladder carcinoma } \\
\text { Pneumonia } \\
\text { Myocardial infarct (death) } \\
\text { Myocardial infarct (death) }\end{array}$ & $\begin{array}{c}65.0 \\
72.0 \\
65.8 \\
64.8 \\
\dot{53.6} \\
\left.33.7^{1}\right)\left(95.7^{2}\right) \\
\left.55.6^{1}\right)\left(80.0^{2}\right) \\
54.3 \\
58.5\end{array}$ & $\begin{array}{l}109.2 \\
96.3 \\
122.3 \\
- \\
- \\
86.7 \\
= \\
-\end{array}$ \\
\hline \multicolumn{3}{|c|}{ Average from $11 / 4$ samples } & 63.5 & 103.6 \\
\hline \multicolumn{3}{|c|}{ Standard deviation } & \pm 16.0 & \pm 15.5 \\
\hline \multicolumn{3}{|c|}{ Values without wall contact } & $\underline{95.6}$ & 120.2 \\
\hline & & & \pm 19.0 & \pm 19.5 \\
\hline
\end{tabular}

\footnotetext{
1) ulcerated plaques

2) "normal" wall
} 


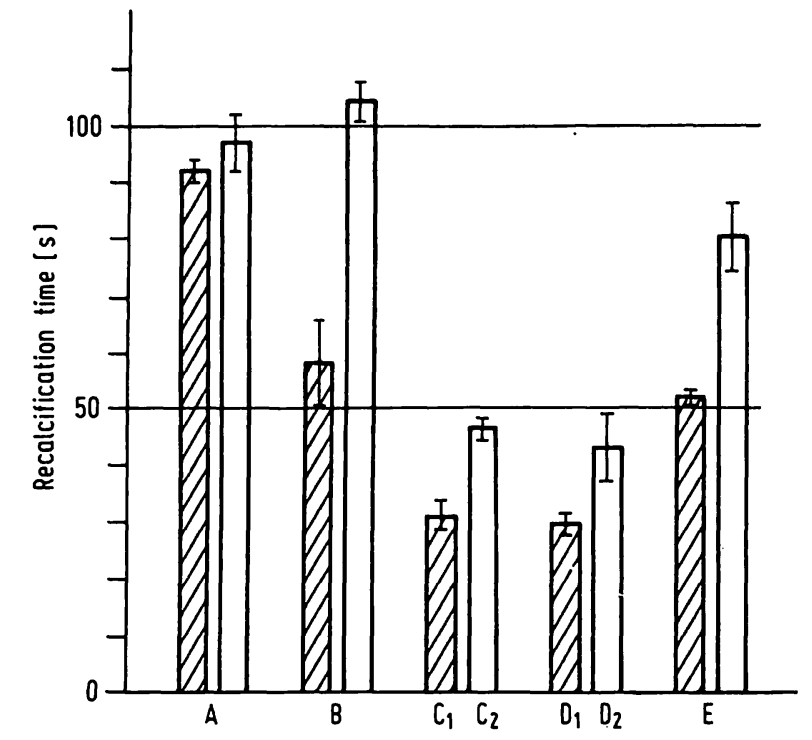

Fig. 1. Recalcification time decreased by segment from earlier recalcification time estimation after repeated washing. Hatched plots represent values from normal plasma, white plots represent values from factor VII-deficient plasma (indicated standard deviations represent 4 experiments).

B: recalcification time in the presence of segment.

A: recalcification time without segment.

B: recalcification time in the presence of segment.

$C_{1}$ : recalcification time repeated with normal plasma and saline-washed segment from $B$.

$\mathrm{C}_{2}$ : recalcification time with factor VII-deficient plasma and segment after recalcification time estimation with normal plasma and saline-washed segment.

$D_{1}$ : recalcification time with normal plasma and salinewashed segment from $\mathrm{C}_{1}$.

$D_{2}$ : recalcification time with factor VII-deficient plasma and segment after 2 fold recalcification time estimation with normal plasma and saline-washed segment.

E: recalcification time with segments from $D_{1}$ and $D_{2}$ after washing with sodium citrate solution, $0.2 \mathrm{~mol} / 1$.

decrease. Thereafter no further decrease could be observed. These effects might be explained by saturation of the thromboplastin molecules of the vessel wall with factor VII from the previous contact with normal plasma, leading to optimal complex formation between tissue thromboplastin and factor VII. Vessel segments preincubated in normal plasma also decreased, to a similar extent, the recalcification time value of factor VII-deficient plasma, since the segment contains the active complex of thromboplastin factor VII a.

When the preincubated segment was washed with 0.2 $\mathrm{mol} / \mathrm{l}$ sodium citrate solution, an increase of recalcification time values was found on repeated estimation. We assume that citrate removes factor VII a from tissue thromboplastin, i.e. destroys the activator complex through $\mathrm{Ca}$-chelation by citrate.

\section{An approach to determine the thromboplastic activity of the different wall structures}

Wall sections were prepared from a fresh aorta, which was carefully freed from any connective tissue and
Tab. 3. Thromboplastic activity in crude preparations of wall layers.

Recalcification time estimation in presence of wall structure

(s)

\begin{tabular}{lll} 
& $\begin{array}{l}\text { Aorta (1) } \\
\text { Segment }\end{array}$ & $\begin{array}{l}\text { Aorta (2) } \\
\text { Segment }\end{array}$ \\
\hline $\begin{array}{l}\text { Endothelium / Basal lamina } \\
\text { (possibly altered by preparation) }\end{array}$ & 52.7 & 60.4 \\
Intima & 54.6 & 89.7 \\
Media & 76.5 & 91.3 \\
Adventitia & 92.0 & 106.2 \\
Without wall segment & 95.0 & 95.0 \\
\hline
\end{tabular}

washed free of blood contaminants with saline. The structures removed, beginning from the inside of the vessel wall, were identified by use of a microscope and a dying-technique using Evans Blue. We assume that the first layer mostly contains disrupted endothelial cells and the basal laminar membrane. The underlying layers represent structures from the intima, media and the adventitia.

Table 3 gives the results of thromboplastic activity found in the various wall structures. Our preparations represented very crude fractions of structures and the estimated values are only approximations. It appears that structures going from inside to outside of the vessel wall contain decreasing amounts of thromboplastic activity. These observations are not new and are herewith confirmed. For induction of thrombogenesis the content of thromboplastic activity in the endothelial and subendothelial layers represents an essential prerequisite.

\section{Discussion}

For the elucidation of thrombogenesis, experiments were carried out using exclusively human arterial tissue and human plasma. The real mechanism of the early phase of thrombogenesis remains still obscure. From own results we assume that the initial reaction after vessel wall damage may be the formation of a complex between thromboplastin localized in the wall and plasma clotting factor VII. Tissue segments of patients do no affect recalcification time of factor VII-deficient plasma appreciably, unless such tissue segments have previously been in contact with normal plasma, thus binding factor VII for subsequent reaction with thromboplastin in the tissue (see experiments in figure 1). An activation of factor XII through contact with altered wall segments does not seem to take place, because no change could be observed in the recalcification time of factor VII-deficient plasma without or with wall segment. Thus it may be concluded that factor VII is essential for normal hemostatic function and induces 
a rapid formation of thrombin upon contact with pathologically available thromboplastin. Thrombin itself may be the trigger for known subsequent reactions, i.e. adhesion and aggregation of thrombocytes and fibrin clot formation. Patients with very low factor VII activity $(\leqslant 1 \%)$ produce severe clotting defects with hemorrhagies into cerebral and mucosal tissues $(3,4)$.

The defect of the clotting mechanism in such patients is not corrected by factor XII activation or other "shunts" for hemostasis. Majerus et al. (5) have found that thrombin must be formed very early in the course of thrombogenesis. But in the case of severe congenital factor XII deficiency no hemostatic complications have been found. This fact diminishes the role of collagenic

\section{References}

1. Freytag, J. W., Dalymple, P. N., Maguire, M. H., Strickland, D. K., Carraway, K. L. \& Hudson, B. G. (1978), J. Biol. Chem. 253, 9069-9074.

2. Lüscher, E. F. (1978), Agents + Actions 8, 282-290.

3. Grosse, K. P., Neidhardt, B., Seiler, G., Schricker, K. Th. \& Dorn, G. (1974), Klin. Pädiat. 168, 29-33. structures as the main physiological trigger in thrombogenesis. Thus thrombin formed via the extrinsic pathway at an early stage induces fibrin formation, platelet adhesion/aggregation and accelerates the activation of the plasmatic coagulation system. Thrombin furthermore is a potent mitogenic substance which may fulfil an important function in wall repair (6).

\section{Acknowledgements}

We thank Dr. B. Nachbur, Surgical Department, Inselspital Bern, and Prof. L. Bianchi, Pathological Institute, University Basel, for gifts of arterial tissues.

4. Zimmermann, R., Ehlers, G., Ehlers, W., von Voss, H., Göbel, U. \& Wahn, U. (1979), Blut 38, 119-125.

5. Majerus, P. W. \& Miletich, J. P. (1978), Ann. Rev. Med. 29, 41-49.

6. Pohl, J., Bruhn, H. D. \& Christophers, E. (1979), Klin. Wochenschr. 57, 273-277.
Dr. H. Zaugg

Diagnostische Forschungsabteilung F. Hoffmann-La Roche \& Co. AG CH-4002 Basel 
